\title{
Myxidium volitans sp. nov., a parasite of the gallbladder of the fish, Dactylopterus volitans (Teleostei: Triglidae) from the Brazilian Atlantic coast - Morphology and pathology
}

\author{
Carlos Azevedo ${ }^{1,2}{ }^{+}$, Graça Casal1,3, Sérgio Carmona São Clemente ${ }^{4}$, Leila Maria Silva Lopes ${ }^{4}$, \\ Patrícia Matos ${ }^{5}$, Abdel Azeem Abdel-Baki², Elsa Oliveira', Edilson Matos ${ }^{6}$ \\ 'Departamento de Biologia Celular, Instituto de Ciências Biomédicas e Laboratório de Patologia, \\ Centro Interdisciplinar de Investigação Marinha e Ambiental, Universidade do Porto, Largo Prof. Abel Salazar 2, P-4099-003 Porto, Portugal \\ 2ZZoology Department, College of Science, King Saud University, Riyadh, Saudi Arabia \\ ${ }^{3}$ Departamento de Ciências, Instituto Superior de Ciências da Saúde-Norte, Gandra, Portugal \\ ${ }^{4}$ Laboratório de Inspeção e Tecnologia dos Alimentos, Faculdade de Veterinária, Universidade Federal Fluminense, Niterói, RJ, Brasil \\ ${ }^{5}$ Laboratório de Animais Aquáticos, Universidade Federal do Pará, Belém, PA, Brasil \\ ${ }^{6}$ Laboratório de Pesquisa Carlos Azevedo, Universidade Federal Rural da Amazônia, Belém, PA, Brasil
}

Myxidium volitans sp. nov. (Myxozoa: Myxidiidae) parasitizing the hypertrophied green-brownish gallbladder of the teleost Dactylopterus volitans, collected in the Atlantic coast near Niterói, Brazil was described based on ultrastructural studies. The spores were fusiform, sometimes slightly crescent-shaped on average $21.7 \pm 0.3 \mu \mathrm{m}$ (mean \pm standard deviation) $(n=50)$ long and $5.6 \pm 0.4 \mu \mathrm{m}(n=30)$ wide. The spore wall was thin and smooth, comprising two equally-sized valves joined by a hardly visible sutural ridge. Spores containing two pyriform polar capsules $(P C)(5.0 \pm 0.4 \times 2.3 \pm 0.3 \mu \mathrm{m})(n=30)$ are situated in each extremity of the spore. The PC wall was composed of hyaline layer (0.20-0.29 $\mu \mathrm{m}$ thick) and by a thin external granular layer. Each PC contains a polar filament (PF) with irregular arrangements that was projected from its apical region to the bases of $P C$ and coiled laterally from bases to the tip of PC. Some regular striations and S-like structures in the periphery of the PFs with four-five irregular sections were observed. Based on the spore morphology, ultrastructural differences and the specificity of the host we describe this parasite as a new myxosporidian, named $\mathrm{M}$. volitans sp. nov.

Key words: Myxozoa - Myxidium volitans sp. nov. - gallbladder - spore - ultrastructure

Beside the considerable information available on myxozoan species collected from different geographical areas (Lom \& Dyková 2006), little is known about those from South America and in particularly about those from the Brazilian Atlantic coasts, where a diverse assemblage of several hundred species of fish live. Within the myxozoans the genus Myxidium is widely distributed infecting several marine and freshwater fishes, some amphibians and reptiles (Lom \& Dyková 2006).

Some Myxidium spp infecting the fish galbladders in the Atlantic ichthyofauna from different regions have been recorded (Lom \& Dyková 1992, 2006, MacKenzie \& Kalavati 1995, MacKenzie et al. 2005): Myxidium incurvatum, collected from several species of the French coasts (Lom \& Dyková 1992), Myxidium sphaericum in Belone belone and other hosts, Myxidium bergensis in Pollachius virens and other hosts, Myxidium oviforme in Pagon imberbis from Mediterranean Sea and in other fish species in the Atlantic Ocean, Myxidium gadi in Pollachius pol-

Financial support: CNPq, CAPES

+Corresponding author: azevedoc@icbas.up.pt

Received 29 December 2010

Accepted 6 June 2011 lachius from French region (Mackenzie \& Kalavati 1995), Myxidium gigantissimum in Alepocephalus australis off South African coast (Dubina \& Isakov 1976), Myxidium baueri in Patagonotothen sima from Falkland Islands (Kovaleva \& Gaevskaya 1982, Kalavati et al. 1996), Myxidium trachinarum in Echiichthys vipera from England (Canning et al. 1999) and Myxidium finnmarchicum in Merlangius merlangus from Norway (MacKenzie et al. 2010) (Table). A Brazilian myxosporidian check-list were published (Gioia \& Cordeiro 1996) in which the great majority of the results were based on light microscopy, however, this record does not report any Myxidium sp. from the Brazilian coast. Until now, Dactylopterus volitans was not reported as a host of Myxidium sp.

This paper describes, based on light and ultrastructural data, a new Myxidium species parasite of a marine fish collected in the Brazilian Atlantic coast.

\section{MATERIALS AND METHODS}

Small fragments of parasitized gallbladder walls and free spores were removed from the bile of the economically important marine fish flying gurnard, D. volitans (Linnaeus, 1758) (Teleostei: Dactylopteridae) (Brazilian common name coió). Sixty four fishes ( 39 males and 25 females) with an average total length of $\sim 25 \mathrm{~cm}$ (range 21$29 \mathrm{~cm})(\mathrm{n}=64)$, collected in the Atlantic coast $\left(22^{\circ} 58^{\prime} \mathrm{S}\right.$ $43^{\circ} 00^{\prime} \mathrm{W}$ ), near the city of Niterói, state of Rio de Janeiro (RJ), Brazil, were examined and the spores were measured 
using Nomarski differential interference contrast microscopy equipped with a micrometric ocular and image software. Measurements were based on fresh spores and data are presented as the mean \pm standard deviation (range).

For transmission electron microscopy (TEM), the free spores and small fragments of parasitized gallbladders were fixed in $5 \%$ glutaraldehyde in $0.2 \mathrm{M}$ sodium cacodylate buffer ( $\mathrm{pH} 7.4)$ for $24 \mathrm{~h}$ at $4^{\circ} \mathrm{C}$, washed overnight in the same buffer at $4^{\circ} \mathrm{C}$ and post-fixed in $2 \%$ osmium tetroxide buffered with the same buffer for $4 \mathrm{~h}$ at the same temperature. After dehydration in an ascending graded ethanol series and propylene oxide, the fragments of gallbladders and free spores were embedded in Epon. Semithin sections were stained with toluidine blue. U1trathin sections, cut with a diamond knife, were doublestained with aqueous uranyl acetate and lead citrate and observed in a JEOL 100CXII TEM operated at $60 \mathrm{Kv}$.

\section{RESULTS}

During a parasitological survey conducted to detect microparasites it was observed that some specimens of the marine fish $D$. volitans showed a hypertrophy of the gallbladder with a green-brownish colour compared with the light green colour of the non parasitized gallbladders. Several developmental life cycle stages and free spores were observed immersed in the bile and located within the epithelial cells of the gallbladder wall (Figs 1-5).

Based in the spore morphology, the parasite was identified as belonging to genus Myxidium Bütschli, 1882 and
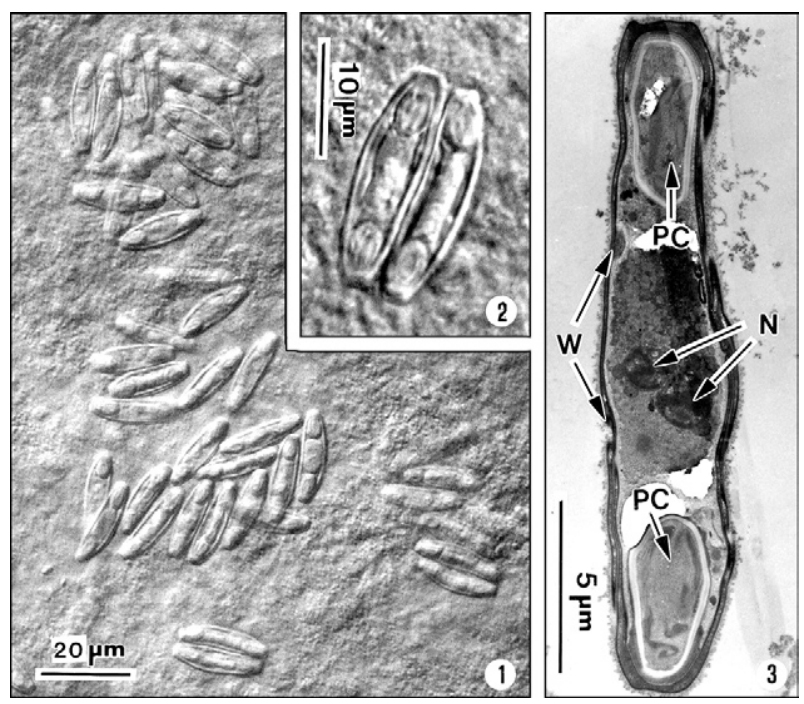

Figs 1-3: light and ultrastructural micrographs of a fish-infecting myxosporean Myxidium volitans sp. nov. found in the gallbladders of the marine fish Dactylopterus volitans collected in the Atlantic Brazilian coast. 1: several free spores observed by differential interference contrast microscopy (DIC); 2: DIC image of two free spores, showing the wall, two evident polar capsules (PC) located at each extremity of the spore and the binucleated sporoplasm cell; 3 : longitudinal section of a spore observed with low magnification showing the spore wall (W), two PCs each at the extremity of the spore and two nuclei $(\mathrm{N})$ of the sporoplasm. following Lom and Dyková (2006), we propose the establishment of a new species classified as follows: Phylum Myxozoa Grassé, 1970, Class Myxosporea Bütschli, 1881, Order Bivalvulida Shulman, 1959, Family Myxidiidae Thélohan, 1892, Genus Myxidium Bütschli, 1882.

\section{Myxidium volitans sp. nov.}

(Figs 1-13)

Description - Developmental stages, including immature and mature spores, with morphological characters of the genus Myxidium Bütschli, 1882 were observed free and immersed in the bile and in the epithelial cells of the gallbladder wall. The development was asynchronous with all the developmental stages and immature spores inter cellular in the epithelial cells of the gallbladder wall (Figs 4-7). Some free mature spores were observed in the initial tract of the intestine. The spore bodies are fusiform, sometime slightly crescent-shaped with smooth surface and more or less rounded ends (Figs 1-3). The spore wall, is thin and smooth, comprised two equal-sized valves without ridges or projections (Figs 1-3). Sutural lines joining valves were hardly visible. Mature fresh spores have the following dimensions: 21.7 $\pm 0.3 \mu \mathrm{m}$ (range 21.3-22.0) $(\mathrm{n}=50)$ in length and $5.6 \pm$ $0.4 \mu \mathrm{m}(5.2-5.9)(\mathrm{n}=30)$ in width and contain two pyriform polar capsules (PC) that are $5.0 \pm 0.4$ (4.6-5.5) $\mu \mathrm{m}$ long and $2.3 \pm 0.3(2.0-2.5) \mu \mathrm{m}(\mathrm{n}=30)$ wide, these are situated in each extremity of the spore (Figs 1-3). The PC wall measured 0.20-0.29 $\mu \mathrm{m}(\mathrm{n}=30)$ thick (Figs 7-11). The PC wall consists of a continuous external dense layer and an internal hyaline thick material which contains an apical pore without a visible stopper (Figs 7-9). The PC contains a polar filament $(\mathrm{PF})$ with irregular arrange-
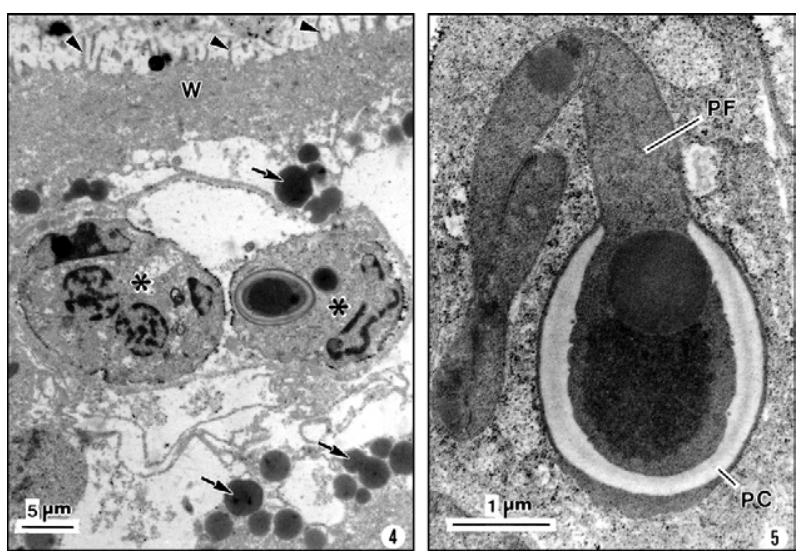

Figs 4, 5: ultrastructural micrographs of Myxidium volitans sp. nov. infecting gallbladders of the marine fish Dactylopterus volitans collected in the Atlantic Brazilian coast. 4: ultrathin transverse section of the periphery of the epithelium of the gallbladder wall (W), showing two developmental stages $(*)$ and several dense bodies (arrows), possibly the components of the bile. The epithelium of the gallbladders wall shows numerous microvilli (arrowheads) projected towards the lumen of gallbladders; 5: ultrathin section of the polar filament (PF) and polar capsule (PC) of a spore maturing process located at the wall tissues of gallbladders. 
ments that is projected laterally from its apical region to the bases of PC and coiled from the bases to the tip of PC (Figs 7-11). Some regular and parallel longitudinal striations were observed at the periphery of the PF. At the matrix of the PC there are 1-2 S-like structures that are adherent to the periphery of the PF (Figs 8-11). Schematic drawings of the spore and PF based on ultrathin serial sections are shown in Figs 12, 13.

Type host - D. volitans (Linnaeus, 1758) (Teleostei: Dactilopteridae) (Brazilian common name coió).

Site of infection - Different developmental stages and immature spores in the epithelial cells of the gallbladder wall and later developmental stages, immature and mature spores immersed in the bile.

Type locality - Atlantic coast near Niterói $\left(22^{\circ} 58^{\prime} \mathrm{S}\right.$ $\left.43^{\circ} 00^{\prime} \mathrm{W}\right)$.
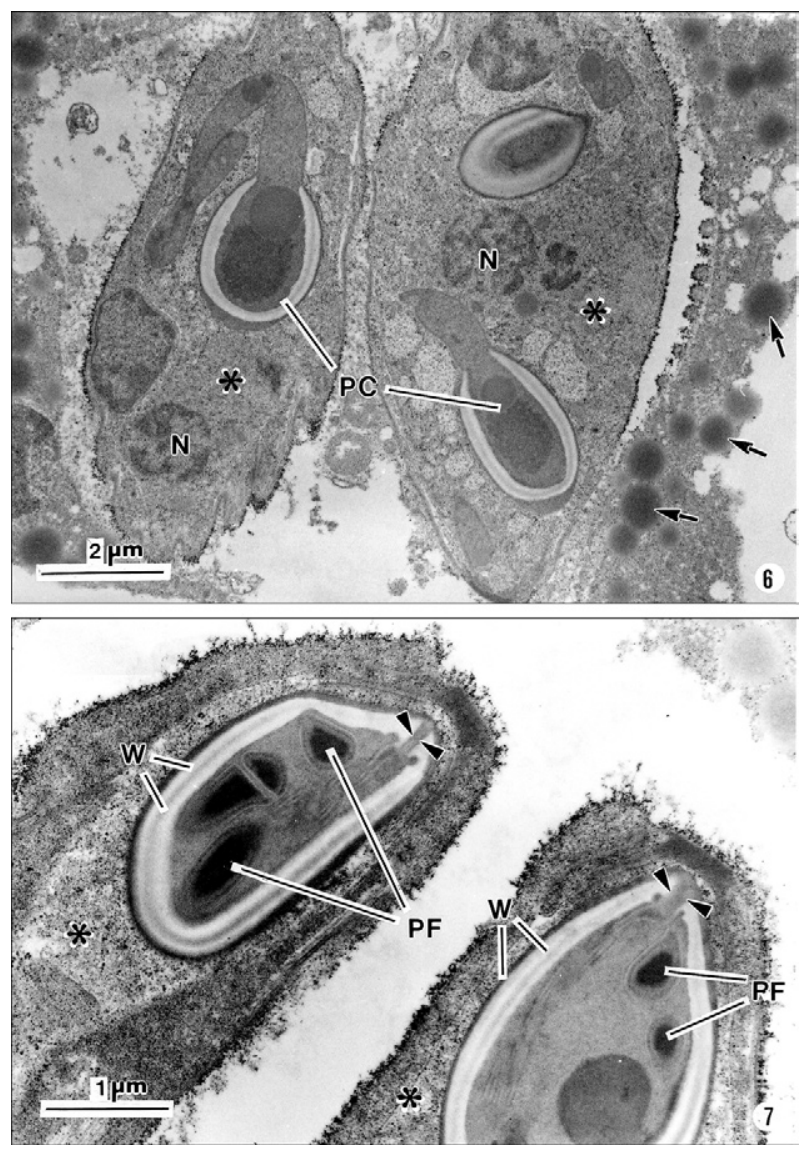

Figs 6, 7: ultrastructural aspects of the spores of Myxidium volitans sp. nov. infecting gallbladders of the marine fish Dactylopterus volitans collected in the Atlantic Brazilian coast. 6: two immature spores (*) observed in the peripheral epithelial cell wall of the gallbladder showing the polar capsules (PC) and the sporoplasm nuclei (N). Several dense droplet structures possibly the bile component (arrows) are located near the spores; 7: extremities of two spores $(*)$ showing the PC wall (W), the longitudinal section of the PCs, some polar filament sections (PF) projected across the PC wall (arrowheads) and the apical pole of the PC without evident stopper covering the pore (2 arrowheads).
Type data and depository - A glass slide with several semithin sections of the mature spores and some other developmental stages of the hapantotypes was deposited in the Myxozoa Type Slide Collection at the Instituto Nacional de Pesquisa da Amazônia - INPA, Amazonas, Manaus, Brazil, under acquisition 004/11.

Prevalence of infection - Twenty two out 64 (40.7\%) of D. volitans specimens [15/39 (38.5\%) for females, $7 / 25$ (28\%) for males].

Pathology signs - The signs of the infection were macroscopically observed by a well evidenced gallbladder hypertrophy and by the appearance of a green-brownish colour of the infected gallbladders in contrast to the light green colour in the non-infected specimens. Some spores were observed in the initial tracts of the intestine.

Etymology - The specific epithet (volitans) is derived from the name of the specific epithet of the genus of the host.
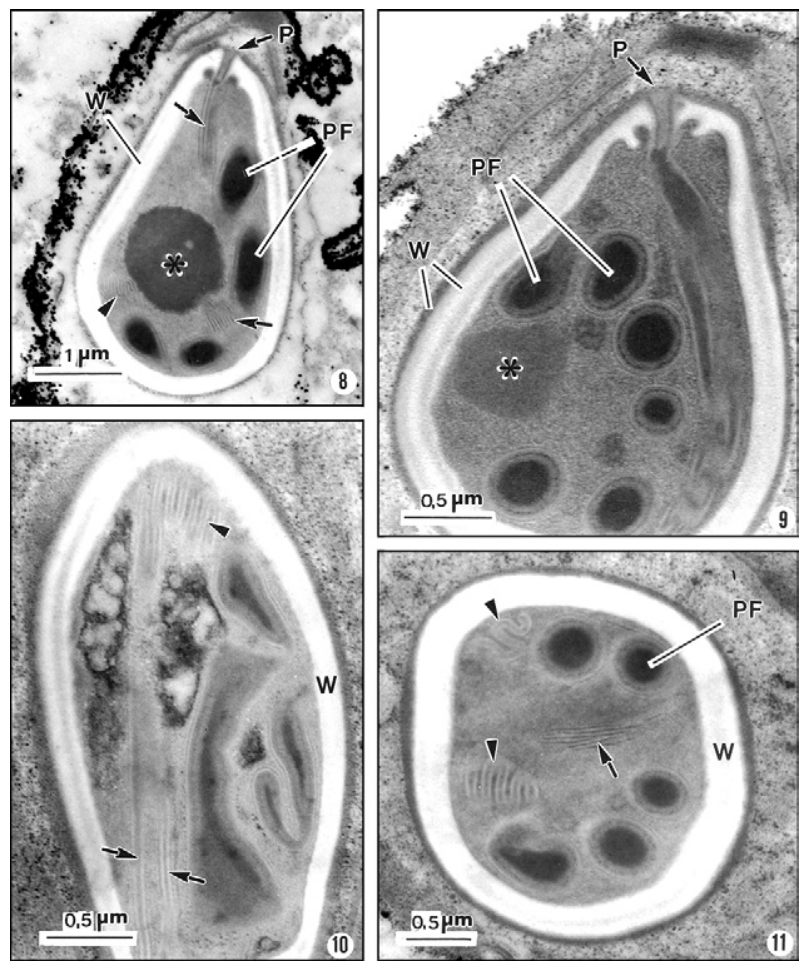

Figs 8-11: ultrastructural aspects of different sections of the polar capsules (PC) and polar filaments (PF) obtained at different levels of Myxidium volitans sp. nov. spores infecting gallbladders of the marine fish Dactylopterus volitans from the Atlantic Brazilian coast. In favourable sections was possible to observe the longitudinal striation $(\mathrm{P})$ at the periphery of the PF (arrows) and some S-like structures (arrowheads) located within the PC matrix. The PC wall (W) composed of two layers: the external one is granulo-fibrillar and dense, while the internal is composed of light hyaline material. Internally the matrix contains some transverse section of the PF. A dense granulo-fibrillar mass $(*)$ appeared frequently in the matrix of the PC. 


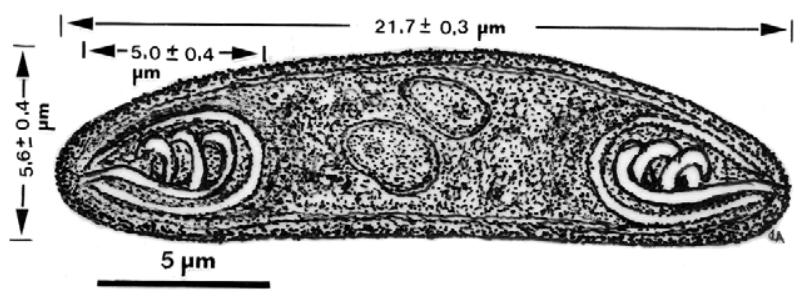

Fig. 12: semischematic drawing of the spore of Myxidium volitans sp. nov. parasite from gallbladders of the marine fish Dactylopterus volitans collected in the Atlantic Brazilian coast showing the morphology of the different structures and there of the marine fish $D$. volitans from the Brazilian coast.

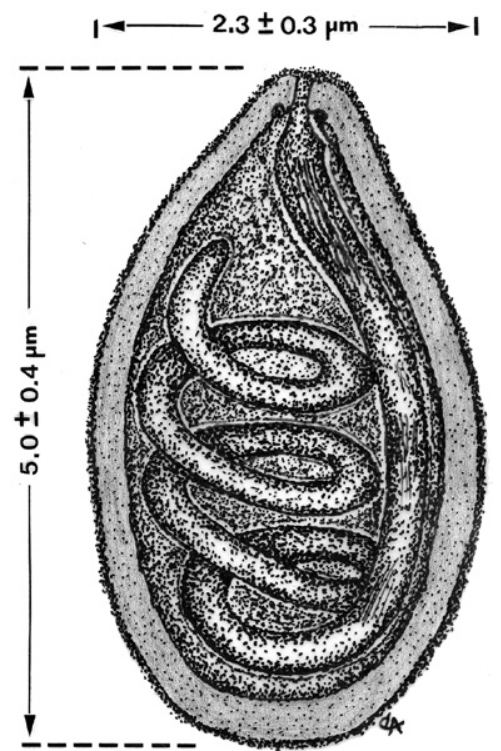

Fig. 13: semischematic drawing of the polar capsule of Myxidium volitans sp. nov. and the arrangements of the polar filament coils obtained by serial ultrathin section observations.

\section{DISCUSSION}

In the present paper we use the light microscopy and ultrastructural data to describe the spores of the myxosporean isolated from the gallbladders of the marine fish $D$. volitans which have widely geographic distribution in the Atlantic Ocean (Eschmeyer \& Demoster 1990). The present study reveals a structural organization and similarities to genus Myxidium Thélohan, 1892 (family Myxidiidae) (Lom \& Dyková 1992, 2006, MacKenzie \& Kalavati 1995). This genus is characterized by having elongated spores, that are slightly crescent-shaped, with two PC in opposite ends, discharge terminally and a longitudinal curved sutural line (Lom \& Dyková 2006).

Considering the separation of marine and freshwater myxosporean species into two major branches (or clades) in results of the recent molecular data using small subunit

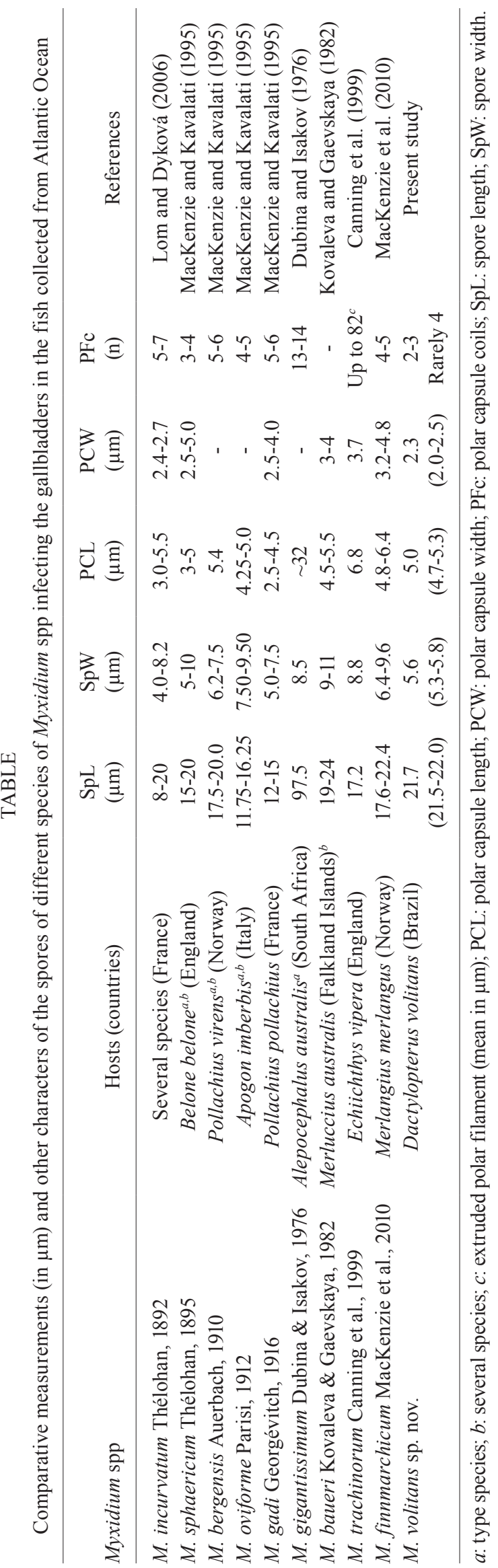


DNA sequences (Kent et al. 2000, 2001, Fiala 2006), we consider for this discussion only Myxidium spp hosted in the marine Atlantic fishes. On the other hand, taking in consideration the role of tissues and organs preferences in differentiating between closely related species for identification of species (Lom \& Dyková 2006), we establish spore comparison only infecting fish gallbladders from hosts collected from Atlantic areas.

So, comparing the characteristics of $M$. volitans sp. nov. (morphology and dimensions of the spore and PCs, number of coils and arrangements of the PFs, and host species), none of these characters were simultaneously equals when compared with those reported for Myxidium spp infecting fish collected in the different geographical areas of the Atlantic Ocean (Table). The spores of $M$. volitans sp. nov. are substantially smaller $(21.7 \pm$ $0.3 \mu \mathrm{m}$ long) than $M$. gigantissimum $(97.5 \mu \mathrm{m}$ long) and larger than M. oviform spores (11.75-16.25 $\mu \mathrm{m})$ and than M. trachinarum spores $(17.2 \mu \mathrm{m})$.

All other spores of the different Myxidium spp reported in the Table have similar ranges and mean of dimensions, however, with different PC arrangement and polar capsule coils $(\mathrm{PFc})$ number.

While the spores of $M$. volitans sp. nov. have PF coiled 2-3 times, in all other species the PFc are coiled more times, excepted the PC of M. sphaericum that have a similar number of PFc (3-4). These two species have, however, different morphology of spores: $M$. volitans have fusiform slightly crescent-shaped with more or less round end, while M. sphaericum have fusiform spores with broad at the centre and a relatively blunt extremity in valvular view (MacKenzie \& Kalavati 1995).

Moreover, the ultrastructural analyses showed the PC and the arrangement of the $\mathrm{PC}$ tapering from its tip to the bases and an irregularly fold from the bases to tip of the PF, and this structural organization is different of those of the previously described species. Additionally the presence of the longitudinal striation on the periphery of the PC and the presence of the some S-like structures in the PC matrix were never reported in the previously described species. And finally, the species here described differs from the previously reported Myxidium spp (Table) in terms of its host specificity (Lom \& Dyková 1992).

The confusion in the literature regarding the validity and host specificity among some of these Myxidium spp recorded in the Table, have been reported some years ago. Considering the similar morphology of the spores of $M$. sphaericum and $M$. bergensis, it was suggested that two of these species may be conspecific (Noble 1957, Moser et al. 1989). Recently was referred and discussed by MacKenzie et al. (2010) the existence of a great confusion and doubt regarding the validity and host specificities of $M$. incurvatum, $M$. phaericum, $M$. bergensis and $M$. gadi which need detailed investigation on the morphological and molecular data.

\section{ACKNOWLEDGEMENTS}

To the technical assistance of Joana and João Carvalheiro.

\section{REFERENCES}

Canning EU, Curry A, Anderson CL, Okamura B 1999. Ultrastructure of Myxidium trachinorum sp. nov. from the gallbladder of the lesser weever fish Echiichthys vipera. Parasitol Res 85: 910-919.

Dubina VP, Isakov LS 1976. New species of myxosporeans from galbladder of deep-sea fish. Parazitologiia 10: 556-560.

Eschmeyer WN, Demoster LJ 1990. Dactylopteridae. In JC Quero, JC Hureau, C Karrer A Post, L Saldanha (eds.), Check-list of the fishes of the eastern tropical Atlantic (CLOFETA), vol. 2, JNICT, Lisboa, p. 690-691.

Fiala I 2006. The phylogeny of Myxosporea (Myxozoa) based on small subunit ribosomal RNA gene analysis. Int $J$ Parasitol 26: 1521-1534.

Gioia I, Cordeiro NS 1996. Brazilian myxosporidians' check-list (Myxozoa). Acta Protozool 35: 137-149.

Kalavati C, Longshow M, MacKenzie K 1996. Two species of myxozoan parasites (Myxosporea: Bivalvulida), including a new genus Patagonotothen sima (Richardson, 1845) (Pisces: Teleostei) in the southwest Atlantic. Syst Parasitol 34: 67-70.

Kent ML, Andree KB, Bartholomew JL, El-Matbouli M, Desser SS, Devlin RH, Feist SW, Hedrick RP, Hoffmann RW, Khattra J, Hallet SL, Lester RJG, Longshow M, Palenzuela O, Siddall ME, Xiao C 2001. Recent advances in our knowledge of the Myxozoa. J Eukaryot Microbiol 48: 395-413.

Kent ML, Khattra L, Hedrick RP, Devlin RH 2000. Tetracapsula renicola $n$. sp. (Myxozoa: Saccosporidae); the PKX myxozoan - the cause of proliferative kidney disease of salmonid fishes. $J$ Parasitol 86: 103-111.

Kovaleva AA, Gaevskaya AV 1982. New species of myxosporeans from fishes of the Falkland-Patagonian region. Parazitologiia 16: 353-359.

Lom J, Dyková I 1992. Myxosporidia (Phylum Myxozoa). Protozoan parasites of fishes. Developments in aquaculture and fisheries science, vol. 26, Elsevier Science, Amsterdam, p. 159-235.

Lom J, Dyková I 2006. Myxozoan genera: definition and notes on taxonomy, life-cycle terminology and pathogenic species. Folia Parasitol 53: 1-36.

MacKenzie K, Collins C, Kalavati C, Hemmingsen W 2010. Myxidium finnmarchicum $\mathrm{n}$. sp. (Myxosporea: Myxidiidae) from the gall bladder of whiting Merlangius merlangus (L.) (Pisces: Teleostei) in North Norway. Zootaxa 2673: 56-64.

MacKenzie K, Kalavati C 1995. Species in the genus Myxidium Bütschli, 1882 (Myxosporea: Bivalvulida) parasitizing the gall bladders of gadid fish in the northeast Atlantic. J Nat Hist 29: 851-863.

MacKenzie K, Kalavati C, Gaard M, Hemmingsen W 2005. Myxosporean gall bladder parasites of gadid fishes in the north Atlantic: their geographical distributions and an assessment of their economic importance in fisheries and mariculture. Fish Res 76: 454-465.

Moser M, Kent ML, Dennis D 1989. Gall bladder Myxosporea in coral reef fishes from Heron Island, Australia. Aust J Zool 37: 1-13.

Noble ER 1957. Seasonal variations in host-parasite relations between fish and their Protozoa. J Mar Biol Assoc UK 36: 143-155. 